\title{
When practice needs more research: the nature and nurture of mathematical giftedness
}

\author{
Roza Leikin ${ }^{1}$ (D) \\ Accepted: 8 May 2021 / Published online: 31 May 2021 \\ (c) FIZ Karlsruhe 2021
}

\begin{abstract}
The educational literature often includes debate over the nature and nurture of mathematical giftedness. The varied schools of thought reflect discrepancies between views, which are to a large extent functions of philosophical, political, and economic considerations. To address this debate, in the context of the current ZDM Special Issue, I attempt to analyze research and practices linked to mathematical giftedness in the Soviet Union in 1960-1980. I also look at the continuation of these Soviet-era practices, and to their influence on practices internationally. Particular attention is paid to the literature devoted to reaching a deeper understanding of the phenomenon of mathematical giftedness and of ways of nurturing this giftedness. The analysis starts with the discussion of domain-specific and domain-general characteristics of mathematical giftedness that have to be taken into account in educational environments for the mathematically gifted. It continues with a review of practices in special mathematical schools and classes in the Soviet Union, and a comparison to similar settings around the world in the twenty-first century. There is also an overview of enrichment mathematical activities, with a focus on mathematical circles, mathematical competitions and Olympiads, accompanied by a description of specificities of the mathematical content employed for the promotion of mathematical giftedness. Finally, the paper focuses on the question of what characterizes an excellent teacher of mathematically gifted students and on new educational technologies that are changing the education of these students worldwide. Following this analysis, I suggest some open questions for future research on the education of mathematically gifted students.
\end{abstract}

Keywords Mathematical giftedness $\cdot$ Activities for mathematically gifted $\cdot$ Specialized mathematics schools $\cdot$ Mathematics competitions and circles $\cdot$ Enrichment accelerations and deepening in mathematics

\section{Introduction}

The education of mathematically gifted students is the subject of a debate in the mathematics education community that echoes the ongoing debate on the education of the gifted in general. This debate includes discussion of core issues on which researchers and educators do not agree. Some of these issues are related to the different answers that psychologists, sociologists, politicians, and economists give when answering questions such as the following: What is the nature and structure of mathematical giftedness? How can mathematical giftedness be advanced and realized? What are the major goals, actions, conditions, and tools that

Roza Leikin

rozal@edu.haifa.ac.il

1 Department of Mathematics Education, RANGE Center, University of Haifa, Haifa, Israel allow effective education of Gifted students? Each of these questions receives a variety of answers depending on the perspective taken, and often the positions are not only different, but opposite.

Often this debate is rooted in the (mis)interpretation of educational equity, while its essence is in providing all students-independently of their abilities — with multiple opportunities to realize and advance their abilities to the maximum extent. Thus, the educational system must equip all students with tools and strategies to learn and enjoy their learning. In particular, mathematical giftedness has to be carefully nurtured for the sake of both personal and public well-being; individual self-esteem; and societal, technological and scientific progress.

In what follows, I start with a literature review that attempts to answer the question, 'What do we know about mathematical giftedness?' with special attention given to domain-specific and domain-general characteristics of 
mathematical giftedness. Then I turn to answering the question, 'How can mathematically gifted students be educated?' I analyze special mathematical schools and classes organized in the former Soviet Union (mainly in the 1960s-1980s) as compared to gifted education nowadays in Russia, other socialist and post-socialist countries, and in the West. I combine analysis of the relevant literature with my reflective account of the experience of studying in the special mathematics school \#30 ${ }^{1}$ in Leningrad (now Saint Petersburg) during 1976-1978. I use the lens of activity theory (Leont'ev, 1978), focusing on goals, activities, conditions and tools related to the education of mathematically gifted students. I consider characteristics of the special mathematical schools, classes, and mathematical content employed for the promotion of mathematical giftedness. Then I turn to mathematical enrichment, including mathematical circles, mathematical competitions, and Olympiads. I discuss education for teachers of the mathematically gifted and address the major shift as educational technologies take on a new role in the education of mathematically gifted students.

\section{What do we know about mathematical giftedness?}

\subsection{Domain-specific characteristics of mathematical giftedness}

The debate about the existence of giftedness is longstanding. For example, in the introduction to Krutetskii's (1968/1976) book, Kilpatrick and Wirszup wrote as follows: "In the Soviet Union, research on individual differences in abilities ceased in 1936 when the Central Committee of the Communist Party banned the use of mental tests. Although achievement tests continued to be used to measure progress in school, other kinds of tests were prohibited to educators and researchers.... It hampered the search for effective instructional procedures" (Kilpatrick \& Wirszup, 1976, p. xii). Twenty years later Krutetskii admitted, "Everybody is more able in some, and less able in other, kinds of activity. To declare someone inept in a certain field (not only in music, the dance, or the fine arts, but in mathematics as well) does not mean that he is inferior or untalented in general. It only means that his abilities lie in other fields" (Krutetskii, 1968/1976, p. 3).

Kolmogorov (https://hr-portal.ru/article/kolmogorovo-razvitii-matematicheskih-sposobnostey), in his letter to Krutetskii written in a response to his research book, The psychology of mathematical abilities in schoolchildren,

\footnotetext{
1 https://en.wikipedia.org/wiki/Saint_Petersburg_Lyceum_30_now St Petersburg Lyceum \#30 specialized in mathematics and physics.
}

stressed that early development of mathematical abilities is especially important for mathematically gifted students. He pointed out that the question "at which age mathematical abilities can be evaluated" is central for the boarding schools that were established in earlier 1960s for mathematically gifted adolescents. Interestingly, he argued that based on his practice working with mathematically talented youth, until the age of 10-12 general development of mental abilities can be sufficient. However, ages 14-15 are critical for the development of special mathematical knowledge and skills. Thus, the entrance examinations to the boarding schools were performed between the 8th and 9th grades. Kolmogorov also noted that formal and validated tools for the evaluation of mathematical abilities had to be developed to support the entrance examination. Kolmogorov linked the highest level of mathematical abilities with "serious scientific work and real scientific discoveries".

Usually, mathematical giftedness is measured by extremely high mathematical performance. Often it is connected to creativity. Professional mathematicians whose mathematical discoveries are recognized by their colleagues (e.g., published in professional journals, awarded with prizes and grants) are ultimately considered mathematically talented individuals (where talent is defined as realized giftedness). The creativity of professional mathematicians led researchers to draw a connection between mathematical talent and mathematical creativity (Hadamard, 1945; Leikin, 2019a, 2019b; Sriraman, 2005). Ervynck (1991), for example, argued that creativity is a critical component of problem solving associated with advanced mathematical thinking that is related to a person's ability to perceive original, non-algorithmic and, often, insight-based solutions. Leikin (2019a) suggested that "A student is mathematically gifted if s/he exhibits a high level of mathematical performance within the reference group and is able to create mathematical ideas which are new with respect to his/her educational history" (p. 3).

In the research domain, in 1955-1966 Krutetskii's research group in the USSR Academy of Pedagogical Sciences' Institute of Psychology conducted research on mathematical giftedness. The work, Psychology of mathematical abilities in schoolchildren was a pioneering study in the Soviet reality. This study paid special attention to the differences in mathematical performance exhibited by "capable, average and incapable" school students.

Krutetskii's (1968/1976) study remains unique to this day due to the size of the research population examined in the study, the combination of cross sectional and longitudinal examinations, the precise design of the series of problems and the richness of research methods used. About 200 school students aged 6-17 were individually interviewed and classified as being in one of 3 levels of mathematical abilities, namely, "capable, average and incapable". More than 1000 
students were followed by the research team to analyze their progress across different school subjects, with a special focus on mathematics. Moreover, a multiple case study was performed with nine especially gifted students using individual interviews. The study led to an understanding of special characteristics essential to high mathematical ability, that include memorization of mathematical content, grasping structures, logical reasoning, ability to generalize, mental flexibility, inclination to search for simple and elegant solutions, and mathematical cast of mind, which is connected to mathematical curiosity and fascination with new ideas.

An extensive longitudinal study of Mathematically Precocious Youth, initiated by Julius Stanley in 1969, was conducted over a period of more than 45 years. The researchers examined the careers of 5000 individuals and demonstrated that these students' mathematical talent was developed into talents in STEM subjects (Lubinski \& Benbow, 2006). The study demonstrated that SAT-M served as a good predictor of high mathematical abilities. Sriraman (2005) analyzed the connection between levels of mathematical creativity and suggested a model that reflects this connection, arguing that mathematical giftedness is an essential component of mathematical creativity at the high level that leads to historical mathematical discoveries. It was shown that the mathematically gifted use different problem-solving strategies, and are able to categorize problems according to solution principles and choose the most efficient ways of solving a particular type of problem. Mathematically gifted students were shown to be able to be more flexible and creative when required to solve problems in multiple ways (in contrast to other students) (Lev \& Leikin, 2017), and to successfully solve insight-based problems (Leikin et al., 2016).

Interestingly, Grigorenko (2017), in her review of general gifted and talented education in Russia in the twentyfirst century, argues that while Russian theoretical literature and practice are rather impressive, the scope of empirical research in the field of the gifted and talented is limited. This argument applies to systematic research on mathematically giftedness. Its rareness is reflected in the very small number of papers in leading mathematics education journals that include 'mathematical giftedness' among their key words. There is a need for systematic investigation in the field aimed to address questions such as the following:

- Are mathematically gifted students good in all branches of mathematics, or does there exist giftedness which is specific to a particular mathematical domain?

- In what ways do gifted students learn mathematics? Can these ways of learning be applied to regular students or they are specific to the mathematically gifted?

- What types of mathematical tasks can best serve for the identification of mathematical giftedness in earlier ages? In elementary school? In middle school?
- Can mathematical insight be considered an ultimate characteristic for the identification of mathematical giftedness in all ages?

- Can mathematical creativity serve as an indicator of mathematical giftedness in school students?

\subsection{Domain-general characteristics of mathematical giftedness}

The resistance to accept giftedness in general and mathematical giftedness in particular as a reality, as well as many speculations about mathematical giftedness, are related to the meaning of the term 'gift'. For example, according to the Merriam-Webster dictionary, gift is "a notable capacity, talent, or endowment" (https://www.merriam-webster.com/ dictionary/gift) and gifted are those "having great natural ability".

On the one hand, these definitions lead to a mistaken belief that if mathematical gift is an endowment, then it determines the mathematical development of individuals 'naturally', that is, independently of the learning opportunities they receive. Mathematical giftedness is viewed as a form of a fixed theory of intelligence, standing in opposition to the 'growth' theory of intelligence that connects intelligence with learning, effort, training, and practice. This distinction is in accord with Dweck (2012) 'theory of mindset' that contrasts between fixed mindset and growth mindset. Boaler (2016) took this one step further, critiquing at once mathematical giftedness, 'fixed mindset' and the assumption that mathematical giftedness is of a genetic nature. Based on these arguments she opposed teaching mathematics for mathematically gifted in special frameworks and advocated teaching all students in heterogeneous classes through hard work.

Karp (2017) wrote as follows:

Today we still know very little about the biological aspect of genius. To be honest, I very much doubt that even 200 years from now, given some improbable, revolutionary discoveries, the detection of potential genius will come down to some kind of test... At the same time, I would not claim categorically that we shall never discover some general biological characteristics common to all known mathematical geniuses. (p. 161)

If we cannot say that there is clear research evidence about the genetic nature of mathematical giftedness, this does not imply that it does not exist. Moreover, research shows that mathematical ability has genetic and environmental etymology (Petrill et al., 2009; Tosto et al., 2014). Petrill et al. (2009) argued that "it cannot be assumed that the skills necessary for high mathematical performance are taught and learned in a genetic vacuum" (p. 378). The goal 
of instruction is to provide the proper sequence of environmental inputs, at the proper intensity. Thus, only specially designed mathematics education can provide mathematically gifted students with tasks requiring hard work in order to realize and maximize their great natural ability. In this way, the 'growth mindset' is essential for the mathematically gifted, and students' awareness of their mathematical giftedness, combined with a growth mindset, can lead them to feel responsible for the prevention of talent loss (Leikin, 2019a).

Over the past two decades more studies on mathematical giftedness have been performed with a focus on domain-general characteristics of mathematical giftedness. Mathematically gifted students have been demonstrated to be better than other students in speed of information processing (Deary, 2000; Leikin et al., 2017; Paz-Baruch et al., 2014, 2016; Steiner \& Carr, 2003) and working memory (Agostino et al., 2010; Leikin et al., 2014; Meyer et al. 2010; O’Boyle, 2005). Neuro-cognitive research has demonstrated the distinctive characteristics of brain activation in mathematically gifted individuals compared to the average population (Butterworth, 1999; Dehaene \& Cohen, 1997; O'Boyle, 2005). These characteristics include(a) the specific neural mechanism of the right cerebral hemisphere (O'Boyle \& Benbow, 1990; Singh \& O'Boyle, 2004), and (b) activation of task-appropriate regions as well as a well-orchestrated and coordinated manner of activation of both hemispheres (Dehaene et al., 1998; O’Boyle, 2005).

To sum up, many studies demonstrate specific characteristics of mathematically gifted students in the mathematical, cognitive and neuro-cognitive domains; however, longitudinal studies can still shed light on the following questions:

- Are basic cognitive traits and neuro-cognitive characteristics predictors of mathematical giftedness, or do they develop in association with mathematical knowledge and skills?

- At which age can mathematical giftedness clearly be identified?

- Which environmental factors are especially critical for the realization of mathematical gift?

\section{How can the mathematically gifted be educated?}

\subsection{Reducing heterogeneity: specialized mathematical schools and classes}

In the Soviet Union the first mathematical schools appeared at the end of the 1950s (Marushina \& McGee, 2016) as "an accident or the outcome of local 'intrigue'... The leadership of the country quite clearly recognized that, for successful military technological competition with the West, specially trained personnel had to be prepared. In addition, trained personnel were needed in many areas, including party leadership" (p. 32). Marushina and McGee (2016) argued that obvious political and economic-military considerations served as the major goal in establishing schools for the mathematically gifted. At the time, the question of the reality of mathematical giftedness was not even raised. The schools (usually physics-mathematics schools) were associated with universities in big cities, and research mathematicians led the process of establishing these schools.

The first four physics-mathematics boarding schools were opened under the guidance of leading universities in Moscow, Leningrad, Novosibirsk, and Kiev. The most famous among them was the Kolmogorov boarding school in Moscow (Karp, 2011). The importance of the boarding schools was in providing an opportunity to develop the mathematical talents of students from remote provinces. In addition to special boarding schools, specialized mathematics or mathematics-physics schools for high school students were established in the big cities. These schools included 9th-10th grade classes (the 2 years before school graduation) where the students were accepted based on their achievements in middle grade school mathematics, results in mathematics Olympiads and individual interviews (Chubarikov \& Pyryt, 1993).

For example, in Leningrad in 1976-1978 (Saint Petersburg nowadays), in addition to specialized mathematics boarding school \#1 there were two specialized mathematics schools, \#30 and \#239. In addition to achievement, as examined in the entrance examinations and interviews, there was a high motivational factor. While they were aware before entering the school of the heavy study load, many students nonetheless chose to travel to and from these schools 6 days a week from different city districts, a journey of more than an hour in each direction. Beyond the heavy study load and high requirements, there was a special atmosphere of trust, mutual respect and support that was challenging and encouraging. Not surprisingly, a very high percent (98\%) of graduates gained entrance to universities of different types. The initial characteristics of specialized mathematics schools were a reduction of the level of heterogeneity of mathematical abilities in classrooms, shared intellectual discourse and common goals and norms.

Additionally, specialized classes for mathematically advanced students appeared in ordinary schools. Karp (2011) noted that in 1970s Leningrad there were 56 specialized classes in regular schools. These classes were less selective than specialized mathematics schools and usually included students from districts close to the school. According to Karp (ibid) it was demonstrated that the test results and the mathematics and physics Olympiads awards received by students from schools \#30 and \#239 were significantly 
higher than those of students in other specialized schools and in the specialized classes. Note here that the number of classes with advanced studies of mathematics increased significantly during Gorbachev's perestroika to prevent the 'good children' from transferring to specialized schools or to mathematics classes in other schools. The specialized mathematical schools and special mathematics classes to this day continue their activities in a similar format, although technological advances have definitely had their influence.

Vogeli $(1997,2016)$ noted that specialized schools have been established in a variety of countries. Hungary has a long and rich tradition of gifted education. "One of the hallmarks of the Hungarian mathematics education system was the formation of special schools for exceptionally talented students" (Stockton, 2010, p. 1). Stockton argued that the origins of special mathematics schools in the Soviet Union and the United States are in the specialized mathematics schools in Budapest founded in the beginning of the twentieth century. Moreover, she wrote, the gifted education systems in Hungary and the United States share many common features. In the 1960s, education for mathematically advanced students in Hungary developed with the addition of specialized classes within select secondary schools (mostly for demographic reasons, Győri et al., 2020). The first such class was organized in 1962 in Fazekas Gymnasium in Budapest and in 2010 there were 11 classes of this kind. Each school also has special classes in other fields such as humanities, foreign languages or natural sciences. The special mathematics classes offer students a chance to learn standard curriculum content on a deeper level as well as to learn content beyond the normal curriculum (Stockton, 2010). In Hungary there was the system of specialized curriculum classes and not specialized schools, as opposed to what happened in this respect in the Soviet Union.

Bruder (2020) described differences in policy related to the education of the mathematically gifted between GDR (German Democratic Republic_-East Germany) and FRG (Federal Republic of Germany-West Germany) separated during the years 1949-1990. Systematic mathematics talent promotion in GDR as influenced by soviet tradition was among the main organizational and structural differences between the school systems in East and West Germany. Bruder (2020) noted that after 1990 "The special schools for mathematics and natural sciences working at a high technical level in the GDR had a hard time surviving with the FRG's concepts of holistic personal development of highly gifted children" (p. 64). Nowadays much attention is given to the education of the mathematically gifted in Germany. In 2001, Hatwig Messner, in collaboration with Linda Sheffield, initiated MCG (international conferences on mathematical creativity and giftedness), that in 2010 turned into the International Group for Mathematical Creativity and Giftedness, which now includes more than 250 educational researchers, mathematicians and mathematics educators. There also exists the World-wide Global Talent Mentoring project for gifted STEM students, led by Heidrun Stoeger (2020 - personal communication). Promoting mathematically gifted students and providing them with special educational settings and content is motivated in part by the PISA 2015 results, which demonstrated that Germany did not have a sufficient number of 'very good' results. However, specialized mathematics schools in Germany remain rare.

When analyzing frameworks for the education of the gifted in the United States, Weinberg (2016) pointed out that special schools and summer camps are well-established and widespread in the country. In New York, special schools for gifted students are directed at the advancement of STEM fields as well as at education in the arts and humanities. STEM education in special schools integrates deepening, enrichment, and acceleration (Weinberg, 2016). In Israel mathematics in high school is taught at 3 levels (basic, regular and advanced) so that mathematically advanced students study within regular schools. Additionally, numerous programs conducted in Israeli Universities are aimed at the development of mathematical talent (Leikin \& Berman, 2016).

King's College London Mathematics School is run in partnership with King's College London University, to provide high quality mathematics education in the heart of London for students who have a fascination with mathematics. The school's website clearly states that "The school was inspired by the Kolmogorov Physics and Mathematics School in Moscow, established in 1965 by Andrey Kolmogorov, one of the leading Mathematicians of the 20th Century." (Scribbr. https://www.kingsmathsschool.com/about).

The history and distinctive features of mathematics schools, and examples of mathematical curricula and mathematical tasks employed in mathematics schools in different countries, are most comprehensively described in the volume "Special secondary schools for the mathematically talented: an international panorama" edited by Vogeli (2016).

\subsection{Mathematical content for the promotion of mathematical giftedness: deepening and broadening mathematical content}

These specialized mathematics schools are characterized by "a separate kind of mathematics developed in specialized schools that is not studied in ordinary schools, and is rarely studied in higher educational institutions" (Karp, 2015, p. 12). This mathematics includes independent problem solving, searching for original problem-solving methods, problem posing, and finding connections between new problems and old ones. Chubarikov and Pyryt (1993) illustrated the curricular principles used at the Kolmogorov School. Broadening mathematical content to include Euclidean and 
Non-Euclidean Geometries, Mathematical Logic, Number Theory and Limit theory was and still is normal. The students studied mathematics $8-10 \mathrm{~h}$ a week, and physics $6 \mathrm{~h}$ a week with additional hours in chemistry and literature. There was a $2 \mathrm{~h}$ per week course on programming. Grigorenko (2017) noticed that often graduates of specialized schools are familiar with content from the university curriculum. While she perceives this as a kind of disconnect between these schools and the University system, many graduates of these schools are happy to deepen their understanding of mathematics in university, having studied the topics in high school in a slightly simplified form.

It should be noted that mathematics teachers in the specialized mathematics schools have a high level of autonomy regarding the way in which they deepen and broaden the mathematical materials, which textbooks they use, and what amount of homework they assign to students. In addition to the high level of mathematics, the teachers integrate humanistic mathematics (Brown, 1996) in their teaching. This includes using intuition in developing understanding of concepts, integrating discovery, competition and cooperation, and developing understand of the value of argumentation. The mathematics lessons integrate complex problem solving with meta-analysis of the solutions, and mathematical investigations with strong logical bases. Providing opportunities for students to think like a mathematician when generating new problems and proving them, and promotion of understanding that in mathematics as in real life there are different solutions to problems, are common elements of mathematical discourse in specialized mathematics classes and schools.

The teachers use different types of mathematically challenging tasks - proving, problem posing, and problem solving which includes careful choice of tasks with respect to the students' progress in the learning process. Oftentimes to increase level of mathematical challenge the teachers implement unconventional tasks, either during the lessons or in the homework. Unconventional tasks are either extracurricular or belong to as-yet-unlearned parts of the school curriculum. Solving unconventional tasks usually is directed at the activation and development of students' mathematical creativity, since it requires students to implement their knowledge and skills in new situations or to construct new ideas for solving the problems. Conventional and unconventional mathematics can be combined when solving one particular problem in multiple ways (Leikin, 2019b).

Special books, such as those by Vilenkin and Shvartsburd (1973) and Vilenkin et al. (1972), were created to fit the special requirements of special mathematics schools. The books were written especially for students of special mathematics schools. The authors stress the high theoretical level of the mathematical content, but at the same time, these books provide opportunities to study mathematics at different levels, since the books include supplementary materials that can be studied as teachers see fit. In addition to conventional tasks, the books include unconventional tasks of the types found in Olympiads. Sharygin $(1982,1984)$ created several problem books which contained geometry problems of different levels of mathematical challenge, many of which were directed at training for participation in mathematical Olympiads. Sharygin (1989) recommended 'changing priorities': these changes included prioritizing ideas when learning a new topic and solving non-routine (heuristic) problems, vs. prioritizing complete answers when working with known ideas and solving standard problems.

Solving problems in different ways, and mathematical investigations, are effective tools for the construction of mathematical connections. When a different solution to a problem belongs to one's personal solution space, one can then form connections among the representations of the mathematical concepts, different mathematical tools and concepts from the same field, or different mathematical topics (e.g., NCTM, 2000). In order to develop connected mathematical knowledge, Russian educators (Davydov, 1996; Sharygin, 1989) promoted implementation of the divergence principle of teaching and learning of mathematics expressed in learning simultaneously several topics connected by unifying mathematical principles, concepts, tools, problem-solving strategies and approaches.

Research focused on the following questions could contribute to our ability to nurture mathematical giftedness effectively:

- What kinds of mathematical tasks are best suited for the education of gifted students?

- What are the principles of design for collections of tasks that are effective for teaching the gifted?

- What is a reasonable ratio between conventional and unconventional problems that suits the goals of teaching the mathematically gifted?

\subsection{Mathematical enrichment-mathematical circles, competitions and Olympiads}

Soviet experiences were rich in different types of frameworks, including mathematics schools, mathematics Olympiads, and mathematical circles (Marushina \& McGee, 2016). These frameworks can be implemented both in-school and out-of-school. Nowadays AP courses, integration of school students in university courses, mentoring of exceptionally talented students by university professors, and virtual mathematics courses are typical out-of-school activities.

Saul (1996) wrote as follows: 
The mathematical circles of the former Soviet Union, and particularly of Leningrad (now St. Petersburg) are quite different from most math clubs across the globe. Typically, they were run not by teachers, but by graduate students or faculty members at a university, who considered it part of their professional duty to show younger students the joys of mathematics... The development of mathematics education is an aspect of Russian culture from which we have much to learn... So we must borrow from our Russian colleagues. (p. vii)

Mathematical circles integrate special kinds of problems and topics, mostly enrichment nature tasks devoted to the development of mathematical talent, curiosity and persistence in overcoming mathematical challenges (Fomin et al., 1996/1992; Vandervelde, 2009). "The goal is to get the students excited about the mathematics they are learning; to give them a setting that encourages them to become passionate about mathematics" (Vandervelde, 2009, p. 9).

Olympiad-related work was very prominent in specialized schools. This work was not equally intensive for all students. The teachers could include Olympiad-type problems in their lessons or homework, in systematic training for Olympiads and other competitions. For example, in 1970-1980 in school \#30 in Leningrad (St. Petersburg), Olympiads were organized in 2 stages: the first was held in written form in school, the second-for winners of the first stage-was oral. The level of problems in the second round usually approached that of the problems in the citywide round of the St. Petersburg Olympiad, which were highly complex (Fomin et al., 1994; Rahim, 1998).

The first well-documented Mathematical Olympiad was the problem-solving contest initiated by the Hungarian Society of Physics and Mathematics in 1894. "The Eötvös Competition is considered the first mathematical Olympiad of the modern world, although Polya and Kilpatrick (1974) pointed out that it was inspired by similar competitions in France and England" (Koichu \& Andzans, 2009, p. 287). As reflected by Karp (2020), in 1960-1980 the framework of Mathematical Olympiads was integrated in the education of mathematically gifted students and constituted an important part of the education of the mathematically gifted in Russia, Poland, Czechoslovakia, Bulgaria, GDR and other Eastern European countries.

The changes that Mathematical Olympiads and competitions go through are related to variability of levels of complexity. Nowadays school mathematical competitions take place along with International Mathematical Olympiad (IMO-https://www.imo-official.org). The well-known Kangaroo mathematics contest is designed with the goal of dissemination of extracurricular mathematical activities to a broad range of students of different ages. Kangaroo mathematics contests include mathematical problems at different levels to allow students of different levels of mathematical knowledge and skills to answer multiple-choice, non-routine problems and enjoy doing mathematics.

Olympiads organized by universities were popular in the former Soviet Union. Students from graduate classes could participate in such Olympiads and got bonuses when entering universities. For the universities, these Olympiads were aimed to identify mathematically promising students and attract them to the universities (Koichu \& Andzans, 2009). Over time, various types of team competitions were invented and introduced. Some mathematical competitions are designed to encourage teamwork and critical thinking (see Fomin et al., 1996). Problems used in mathematical Olympiads and competitions are mostly of the enrichment type, often integrated in teaching mathematics in specialized schools and classes and, overall, alongside their role in the development of mathematical talent, mathematics Olympiads play a significant role in the popularization of mathematics.

Activities for mathematically gifted students nowadays are integrated in the more general frameworks devoted for the development of high abilities. The world leader in gifted education since 1971, Johns Hopkins Center for Talented Youth, was founded in 1971 by Professor Julian Stanley. At different stages, centers for the education of gifted students were established in many universities, and many of these centers had special sub-programs for mathematically gifted students. Nowadays many universities around the world open their doors to mathematically gifted youth, providing them with enrichment activities, summer camps and AP (advanced placement) courses (e.g., https://cims.nyu.edu/ cmt/index.html; http://www.promys.org//.

As stated earlier. research reports and papers in high-level research journals in mathematics education and gifted education that present systematic studies on the development of mathematical talent are rare. More research is needed to explain the mechanisms of mathematical talent development and the impact of educational programs for mathematically gifted students. In this paper I do not analyze the role of mathematical creativity in the development of mathematical talents. While research and educational literature as early as that by Poincare (1908/1952) indicates that a high level of creativity is an intrinsic characteristic of any research mathematician (Sriraman, 2005), still, research does not provide sufficient information regarding the effect of creative activities on the development of expertise and the effect of longterm development of a high level of mathematical expertise on creativity. Elgrably and Leikin (2021) demonstrated that training for International Mathematical Olympiads leads to a higher level of creativity associated with geometry investigations. However, more research on the connections between the role of creativity directed activities, and the balance between training and creative activities in realization of 
mathematical giftedness, is needed. Research focused on the following questions could help us to better understand activities integrated in enrichment and acceleration programs:

- How does learning mathematics in out-of-school programs differ from in-school study of mathematics?

- How do mathematical competitions influence students' affect related to learning mathematics?

- Does participation in mathematics circles and other enrichment programs influence student learning in mathematics classes in school?

- How can students be most effectively trained for mathematical Olympiads?

- To what extent does developing mathematical expertise with complex problem solving develop mathematical creativity as expressed in the ability to advance mathematics as a scientific field?

\subsection{Teachers of gifted students}

As I reported in Leikin, 2011, I analyzed the components of expertise of a teacher of mathematically gifted students who worked in a special mathematics school (Leningrad school \#30 mentioned earlier). The analysis of his teaching principles and techniques was based on his paper about teaching the mathematically gifted (Maizelis, 2007), his graduates' memories, and my own retrospective analysis. Naturally, teachers' professional knowledge and mastery of teaching skills appeared to be central. These together with the teacher's personality and broad general knowledge contribute to the effectiveness of the teaching directed at the development of qualities that a teacher can develop in gifted students (Karp, 2007, 2010; Leikin, 2011). Among the identified principles, the following appeared to be especially important for teachers of gifted:

- Teachers' genuine interest in the subject and readiness for any challenge (from the students) makes teaching both interesting and challenging for students, and develops in students motivation, curiosity, willingness to cope with difficulties, and-most importantly—love of the subject.

- Teachers' kindness to students and pride in their successes leads to respectful teaching that advances students' respect, kindness, and support for peers.

- Teachers' creativity creates opportunities for inspiring and open atmosphere that develops in students' creative and independent thinking.

- The teachers of gifted students should be patient and sensitive, with deep knowledge related to the psychology of gifted children and the didactics of teaching them.

- Explicit expressions of love of mathematics and a sense of humor allow for the overcoming of difficulties in a positive atmosphere, and joyful learning that advances students' sense of humor and kindness.

These teachers' qualities allow differential education and vision-important, as even gifted classes are heterogeneous with respect to students' abilities - which lead to education that develops persistence and responsibility. The findings are consistent with the ideas of Maker (1975), who maintained that there a unique combination of character traits that is essential for high quality teaching of gifted students. Maker stressed the importance of the teacher providing students with a secure environment and warm atmosphere that reduces peer pressure and leads to mutual respect among the students and development of students' awareness that their ideas are valuable.

Questions for further research include the following:

- Should the teachers of gifted students be gifted themselves?

- What kind of special training should teachers of mathematically gifted students receive?

I suggest that mathematics teacher education programs should integrate courses on the characterization of mathematically gifted students, programs for the mathematically gifted, and task design for the mathematically gifted.

\section{Does use of technology in education change gifted education?}

It is obvious that the most prominent changes in all areas of life-engineering, medicine, natural sciences, communication and social media - are related to technological advancements that happen on an everyday basis. These advancements influence education in general and education of the gifted in particular (e.g., Freiman \& Paths, 2018). During COVID-19 we learned about additional ways in which gifted students can study mathematics, and over the next decade we will surely learn more about the impact of technological progress on education in general and the education of the gifted in particular. The questions of how, when, and why technology can and should be used in the education of the mathematically gifted have become salient.

In general, education benefits from technological advances. The use of technology can be distributed among multiple settings and allow shared spaces of instructional resources, tasks and ideas. There has been a rapid increase in access to information and to novel kinds of technologically mediated learning environments such as online special interest groups, tutorials, and games. It has become easier for those with computer access to find resources and activities that can support their learning on their own terms. 
Technology-based learning activities can integrate information resources, e-books, interactive projects, online classes, publishing platforms, and mentoring resources. Internet use allows more intensive integration of learning through gaming as well as collaborative learning with internet-based communication. Interaction between students and teachers as well as between students can be ongoing through different kinds of applications such as WhatsApp or Telegram.

Literature on general gifted education points out that technology use has become customary in education in general and in the education of the gifted in particular (Chen et al., 2013). Chen, Dai and Zhou introduced conceptualization of such uses of technology in the "enable, enhance, and transform" working framework. Employing technology in gifted education has high potential to enable activities for the gifted in new geographic regions, enhance the quality of gifted education, and transform gifted education through the integration of the new forms and tools. It is also widely accepted that technology has great potential for enhancing the efficiency and quality of gifted education; some scholars even assert that certain technologies are particularly beneficial to gifted students (Pyryt, 2009; Siegle, 2005).

This view can be applied to the educational activities of mathematically gifted students. The enabling function of technology allows reaching a larger number and more diverse range of talented students. Enabling the function of technology opens multiple opportunities for the mathematically gifted to access a broad range of internet-based activities and resources, and makes participation in online mathematical competitions and contests more accessible. Online courses and virtual schools for the mathematically gifted have been established. For example, the NRICH project (http://www.nrich.maths.org), located at Cambridge University, offers rich mathematical tasks to learners from 5 to $18+$ years of age, and support for their teachers and parents. Promyse camps for the mathematically gifted were conducted in a virtual format (http://www.promys.org/). The use of technological tools in teaching the mathematically gifted allows differentiated learning in gifted classrooms, and increases the ease of performing mathematical investigations.

Mathematical instruction for all, and especially for the mathematically gifted, can be transformed using dynamic software that allows students to conduct mathematical investigations. These investigations have a dual effect: on the one hand, they develop creativity by providing opportunities for mathematical discovery, and on the other hand they support the development of mathematical expertise by deepening students' understanding of mathematical structures by means of dynamic visualization. The transformation function of technology also can be seen in the development of assessment tools (i.e., computerized adaptive testing) that can assist teachers with on-line information about students' learning progress, support students' self-regulated learning, and provide researchers and educators with more precise evaluation and identification of students' mathematical abilities.

New technological and scientific advancements also lead to new areas of research on mathematical creativity and giftedness. Neurocognitive studies on mathematical giftedness, genetic studies as well as machine deep learning, can probably better resolve many questions about the nature and structure of the mathematical mind. Still more research is needed to shed light on the influences of technology on learning and teaching in general and on the education of the mathematically gifted in particular. For example, the following questions may be of interest to researchers:

- How do students interact with the technology and environment and advance their knowledge and skills?

- What is the impact of technological tools on the development of mathematical expertise and creativity in mathematically gifted students?

\section{Concluding notes}

In the context of this special issue, I tried to identify activities provided for the education of mathematically gifted students in the former Soviet Union, and the changes that have occurred in the education of the mathematically gifted over the past four decades. I must admit that the forms of gifted education that exist today continue traditions that were established in the 1960s and 1970s. Acceleration, enrichment and deepening are still the main approaches for teaching the gifted seven decades later. Mathematical schools, classes, circles and clubs, as well as mathematical competitions and Olympiads, continue functioning. Special instructional materials continue to be published. The major changes, though, seem to be related to the opportunities provided by the internet and other technological tools that increase accessibility and enhance and transform activities for the mathematically gifted.

It seems that education of mathematically gifted students can be seen as a kind of general gifted education. However, in the frameworks of the European Council for High Ability (https://www.echa.info/) and the World Council for Gifted and Talented Children (https://world-gifted.org), mathematical giftedness and talent is infrequent. Fortunately, in the field of mathematics education the establishment (in 2010) of the International Group for Mathematical Creativity and Giftedness (https://www.igmcg) associated with ICME can be seen as an acknowledgement of the importance of this educational and research field. This paper proposes directions for future research that can advance our understanding of the nature and nurture of mathematical giftedness and 
inform educators about better ways of realizing and advancing mathematical abilities.

\section{References}

Agostino, A., Johnson, J., \& Pascual-Leone, J. (2010). Executive functions underlying multiplicative reasoning: Problem type matters. Journal of Experimental Child Psychology, 105(4), 286-305.

Boaler, J. (2016). Mathematical mindsets: Unleashing students' potential through creative math, inspiring messages and innovative teaching. Jossey-Bass.

Brown, S. (1996). Towards humanistic mathematics education. In A. J. Bishop, M. K. Clements, C. Keitel, J. Kilpatrick, \& C. Laborde (Eds.), International handbook of mathematics education (Vol. 4, pp. 1289-1321). Springer Science and Business Media.

Bruder, R. (2020). 2 traditions and changes in the teaching and learning of mathematics in Germany. In A. P. Karp (Ed.), Eastern European mathematics education in the decades of change (pp. 45-74). Springer.

Butterworth, B. (1999). The mathematical brain. Macmillan.

Chen, J., Dai, D. Y., \& Zhou, Y. (2013). Enable, enhance, and transform: How technology use can improve gifted education. Roeper Review, 35(3), 166-176.

Chubarikov, V. N., \& Pyryt, M. C. (1993). Educating mathematically gifted pupils at the Kolmogorov School. Gifted Education International, 9(2), 110-111.

Davydov, V. V. (1996). Teoriya razvivayushego obucheniya (Theory of developing education). Intor.

Deary, I. J. (2000). Looking down on human intelligence: from psychometrics to the brain. Oxford University Press.

Dehaene, S., \& Cohen, L. (1997). Cerebral pathways for calculation: Double dissociation between rote verbal and quantitative knowledge of arithmetic. Cortex, 33, 219-250.

Dehaene, S., Dehaene-Lambertz, G., \& Cohen, L. (1998). Abstract representations of numbers in the animal and human brain. Trends in Neurosciences, 21(8), 355-361.

Dweck, C. S. (2012). Mindset: The new psychology of success. Constable \& Robinson Limited.

Elgrably, H., \& Leikin, R. (2021). Creativity as a function of problem-solving expertise: Posing new problems through investigations. ZDM-Mathematics Education. https://doi.org/10.1007/ s11858-021-01228-3

Ervynck, G. (1991). Mathematical creativity. In D. Tall (Ed.), Advanced mathematical thinking (pp. 42-53). Kluwer.

Fomin, D., Genkin, S., \& Itenberg, I. (1996). Mathematical circles (Russian experience) [M. Saul, Trans.]. American Mathematical Society.

Fomin, D. V., Fomin, D., \& Kirichenko, A. (1994). Leningrad mathematical olympiads 1987-1991. (Vol. 1). MathPro Press.

Freiman, V., \& Paths, I. (2018). Leveraging mathematics creativity by using technology: Questions, issues, solutions, and innovative paths. In V. Freiman \& J. L. Tassell (Eds.), Creativity and technology in mathematics education: Mathematics education in the digital era (pp. 3-28). Springer.

Grigorenko, E. L. (2017). Gifted education in Russia: Developing, threshold, or developed. Cogent Education, 4(1), 1364898. https:// doi.org/10.1080/2331186X.2017.1364898

Győri, J. G., Fried, K., Köves, G., Oláh, V., \& Pálfalvi, J. (2020). The traditions and contemporary characteristics of mathematics education in Hungary in the post-Socialist era. In A. P. Karp (Ed.), Eastern European mathematics education in the decades of change (pp. 75-130). Springer.
Hadamard, J. (1945). The psychology of invention in the mathematical field. Dover.

Karp, A. P. (Ed.). (2007). A. R. Maizelis: In Memoriam [Pamiati A. R. Maizelisa]. SMIO Press. In Russian.

Karp, A. P. (2010). Teachers of the mathematically gifted tell about themselves and their profession. Roeper Review, 32(4), 272-280.

Karp, A. P. (2011). Schools with an advanced course in mathematics and schools with an advanced course in the humanities. In A. P. Karp \& B. R. Vogeli (Eds.), Russian mathematics education: Programs and practices (pp. 265-318). World Scientific.

Karp, A. P. (2015). A brief history of specialized mathematics schools. In B. R. Vogeli (Ed.), Special secondary schools for the mathematically talented: An international panorama (Vol. 12, pp. 1-17). World Scientific.

Karp, A. P. (2017). Some thoughts on gifted education and creativity. ZDM Mathematics Education, 49, 159-168.

Karp, A. P. (Ed.). (2020). Eastern European mathematics education in the decades of change. Springer.

Kilpatrick, J., \& Wirszup, I. (1976). Introduction. The psychology of mathematical abilities in schoolchildren. University of Chicago Press.

Koichu, B., \& Andzans, A. (2009). Mathematical creativity and giftedness in out-of-school activities. In R. Leikin, A. Berman, \& B. Koichu (Eds.), Creativity in mathematics and the education of gifted students (pp. 285-308). Sense.

Kolmogorov, A. N. About mathematical abilities: Letter to V. A. Krutetskii. Scribbr. https://hr-portal.ru/article/kolmogorov-o-razvi tii-matematicheskih-sposobnostey.

Krutetskii, V. A. (1968/1976). The psychology of mathematical abilities in schoolchildren [J. Teller, Trans.; J. Kilpatrick \& I. Wirszup, Eds.]. The University of Chicago Press.

Leikin, R. (2011). Teaching the mathematically gifted: Featuring a teacher. Canadian Journal of Science, Mathematics and Technology Education, 11, 78-89.

Leikin, R. (2019a). Giftedness and high ability in mathematics. In S. Lerman (Ed.) Encyclopedia of mathematics education. 10-page entry. Springer. https://doi.org/10.1007/978-3-319-77487-9_65-4 (Electronic Version)

Leikin, R. (2019). Developing mathematical talent in schoolchildren: Who, What, and How? In R. F. Subotnik, P. Olszewski-Kubilius, \& F. C. Worrell (Eds.), The psychology of high performance: Developing human potential into domain-specific talent (pp. 173-192). American Psychological Association.

Leikin, R., \& Berman, A. (2016). Mathematics for students with high mathematical potential in Israel. In B. R. Vogeli (Ed.), Special secondary schools for the mathematically talented: An international panorama (Vol. 12, pp. 117-143). World Scientific.

Leikin, R., Paz-Baruch, N., \& Leikin, M. (2014). Cognitive characteristics of students with superior performance in mathematics. Journal of Individual Differences, 35(3), 119-129.

Leikin, R., Waisman, I., \& Leikin, M. (2016). Does solving insightbased problems differ from solving learning-based problems? Some evidence from an ERP study. ZDM Mathematics Education, $48(3), 305-319$. Special issue on neuro-science and mathematics education.

Leikin, R., Leikin, M., Paz-Baruch, N., Waisman, I., \& Lev, M. (2017). On the four types of characteristics of super mathematically gifted students. High Ability Studies, 28(1), 107-125.

Leont'ev, A. N. (1978). Activity, consciousness, and personality. Prentice-Hall.

Lev, M., \& Leikin, R. (2017). The interplay between excellence in school mathematics and general giftedness: Focusing on mathematical creativity. In R. Leikin \& B. Sriraman (Eds.), Creativity and giftedness: Interdisciplinary perspectives from mathematics and beyond (pp. 225-238). Springer. 
Lubinski, D., \& Benbow, C. P. (2006). Study of mathematically precocious youth after 35 years: Uncovering antecedents for the development of math-science expertise. Perspectives on Psychological Science, 1, 316-345.

Maizelis, A. R. (2007). Notes of an old teacher. In A. P. Karp (Ed.), A. R. Maizelis: In memoriam [Pamiati A. R. Maizelisa] (pp. 19-32). Berlin: SMIO Press. In Russian.

Maker, C. J. (1975). Training teachers for the gifted and talented: A comparison of models. The Council for Exceptional Children.

Marushina, A., \& McGee, D. (2016). Russian mathematics schools. In B. R. Vogeli (Ed.), Special secondary schools for the mathematically talented: An international panorama (pp. 31-47). World Scientific.

Meyer, M. L., Salimpoor, V. N., Wu, S. S., Geary, D. C., \& Menon, V. (2010). Differential contribution of specific working memory components to mathematics achievement in 2nd and 3rd graders. Learning and Individual Differences, 20, 101-109.

National Council of Teachers of Mathematics. (2000). Principles and standards for school mathematics. NCTM.

O'Boyle, M. W. (2005). Some current findings on brain characteristics of the mathematically gifted adolescent. International Education Journal, 6, 247-251.

O'Boyle, M. W., \& Benbow, C. P. (1990). Handedness and its relationship to ability and talent. Advances in Psychology, 67, 343-372.

Paz-Baruch, N., Leikin, M., Aharon-Peretz, J., \& Leikin, R. (2014). Speed of information processing in generally gifted and excelling in mathematics adolescents. High Abilities Studies., 25(2), 143-167.

Paz-Baruch, N., Leikin, M., \& Leikin, R. (2016). Visual processing in generally gifted and excelling in school mathematics adolescents. Journal for the Education of the Gifted, 39(3), 237-258.

Petrill, S. A., Kovas, Y., Hart, S. A., Thompson, L. A., \& Plomin, R. (2009). The genetic and environmental etiology of high math performance in 10-year-old twins. Behavior Genetics, 39(4), $371-379$.

Poincare, H. (1908/1952). Science and method. Dover Publications.

Polya, G., \& Kilpatrick, J. (1974). The Stanford mathematics problem book with hints and solutions. Teacher College Press.

Pyryt, M. C. (2009). Recent developments in technology: Implications for gifted education. In L. V. Shavinina (Ed.), International handbook on giftedness (pp. 1173-1180). Springer.

Rahim, M. H. (1998). Leningrad mathematics Olympiads 1987-S991. School Science and Mathematics, 98(1), 48.

Saul M. (1996). Foreword. In D. Fomin, S. Genkin \& I. Itenberg (Eds.), Mathematical circles (Russian experience) [M. Saul, Trans.] (pp. vii-viii). American Mathematical Society.

Sharygin, I. F. (1982). Zadachi po geometrii (Planimetriya). [Problems in Geometry (Plane Geometry)]. Nauka.
Sharygin, I. F. (1984). Zadachi po geometrii (Stereometriya). [Problems in Geometry (3-dimensional geometry)]. Nauka.

Sharygin, I. (1989). Mathematics beyond the school. Nauka.

Siegle, D. (2005). Using Media \& Technology with Gifted Students. Prufrock Press.

Singh, H., \& O’Boyle, M. W. (2004). Interhemispheric interaction during global-local processing in mathematically gifted adolescents, average-ability youth, and college students. Neuropsychology, $18(2), 371$.

Sriraman, B. (2005). Are giftedness and creativity synonyms in mathematics? An analysis of constructs within the professional and school realms. Journal of Secondary Gifted Education, 17, 20-36.

Steiner, H. H., \& Carr, M. (2003). Cognitive development in gifted children: Toward a more precise understanding of emerging differences in intelligence. Educational Psychology Review, 15, 215-246.

Stockton, J. (2010). Education of mathematically talented students in Hungary. Journal of Mathematics Education at Teachers College, $2,1-6$.

Tosto, M. G., Hanscombe, K. B., Haworth, C. M., Davis, O. S., Petrill, S. A., Dale, P. S., \& Kovas, Y. (2014). Why do spatial abilities predict mathematical performance? Developmental Science, $17(3), 462-470$.

Vandervelde, S. (2009). Circle in a box. Mathematical Sciences Research Institute and American Mathematical Society.

Vilenkin, N. Y., Guter, R. S., Shvartsburd, S. I., Ovchinsky, B. V., \& Ashkinuze, V. G. (1972). Algebra [Algebra]. Prosveschenie.

Vilenkin, N. Y., \& Shvartsburd, S. I. (1973). Matematicheskii analiz [Calculus]. Prosveschenie.

Vogeli, B. R. (1997). Special secondary schools for the mathematically and scientifically talented: An international panorama. Columbia University.

Vogeli, B. R. (Ed.). (2016). Special secondary schools for the mathematically and scientifically talented. An international panorama. Word Scientific.

Weinberg, S. (2016). Specialized high schools in New York City. In B. R. Vogeli (Ed.), Special secondary schools for the mathematically talented: An international panorama (Vol. 12, pp. 49-64). World Scientific.

Publisher's Note Springer Nature remains neutral with regard to jurisdictional claims in published maps and institutional affiliations. 